\title{
Child-Killing and Emotion in Early Modern England and Wales
}

\section{Garthine Walker}

This chapter explores emotional responses to child-killing in early modern England and Wales. ${ }^{1}$ Of unnatural infant deaths, newborn child murder has received the greatest attention in historical scholarship, particularly neonatal infanticide prosecuted under the 1624 Concealment Act. ${ }^{2}$ The premise of this statute was that unmarried women who concealed their pregnancies, murdered their newborn infants, and secretly disposed of the bodies avoided conviction by claiming stillbirth. Concealment of death rather than homicide thus became the fact to be determined in law. ${ }^{3}$

The infanticidal mother's story-or, at least, the unfolding of events that culminated in prosecution under the Concealment Act-is well known. It is a tale in which emotions are central: shame, isolation and fear on her part and disapproval and contempt on that of neighbours and legal officials. It is also a story of progress in which again emotions play a key role. An increased acquittal rate in the eighteenth century is explained in terms of the development of modern sensibilities, which led juries to

\footnotetext{
G. Walker $(\square)$

Cardiff University, Cardiff, UK

e-mail: walkergm@cardiff.ac.uk
}

(C) The Author(s) 2016

K. Barclay et al. (eds.), Death, Emotion and Childhood in

Premodern Europe, Palgrave Studies in the History of Childhood, DOI 10.1057/978-1-137-57199-1_8 
become more sympathetic to defendants. This attribution of 'modern' feelings to eighteenth-century people is extended, perhaps inadvertently, to women accused of infanticide across the period. By imposing upon the infanticidal mother a subjective experience that may be similar to that which we could imagine for ourselves, we run the risk of distancing ourselves from other historical subjects: the people who prosecuted them and the infants who were deprived of life. A question arises, therefore, of whose emotions the historiography of infanticide has so far privileged.

Here, I examine anew contemporary attitudes towards women suspected of killing infants and to discovering infant corpses; I end by revisiting how we may approach the subjectivities of accused women. Drawing on late sixteenth-, seventeenth- and eighteenth-century English and Welsh sources, I show that emotional reactions to child-killing were complex and variable. Such responses cannot be reduced to a narrative in which premodern harshness was replaced by modern empathy.

\section{The Infanticidal Mother's Story}

In February 1734, Jane Williams confessed before magistrates that three weeks earlier she had been 'delivered of a female bastard, born dead' in her house in north Wales. Alone during her labour, she afterwards buried the child in an 'aisle in the said dwelling house privately, without acquainting any person about it'. ${ }^{4}$ Jane was convicted at the Montgomeryshire Great Sessions (the Welsh equivalent of the English Assizes) and sentenced to hang. Any modern scholar is likely to fashion from Jane's brief confession a variant of a generic story constructed in the shadow of the 1624 Concealment Act. A woman who found herself pregnant and abandoned by the father of the child, fearing the censure of her community, concealed the signs of pregnancy and told no one. She gave birth alone with neither practical nor emotional support. Afterwards, whether the child had been stillborn, survived for minutes or hours, or died by neglect or her own hand, she secretly disposed of its body. The discovery of the corpse precipitated a search for the mother, who was identified by material signs of childbirth on bed-linen or elsewhere, by visible changes in her body, or other seemingly incriminating behaviour. The woman was interrogated by magistrates who took sworn statements from witnesses, and thereafter tried at the Assizes or Great Sessions where she was convicted, effectively, of murder. She died on the gallows, or narrowly escaped with her life, a victim of a patriarchal society in which the shame of bearing an illegitimate 
child compelled her to murder her newborn babe or allow it to die. So the story goes. ${ }^{5}$

We may construct such a story in Jane Williams's case. Several female neighbours deposed that Jane, who had recently grown so 'very big', suspiciously emerged much 'smaller' after a period of supposed sickness during which she stayed home and refused visitors. Jane initially denied everything. She displayed her breast to local women when asked to do so but would not allow them to 'draw or suck a little' to confirm whether she was lactating, which she seemed to be. Fearing the worst, the women informed magistrates, who sanctioned a search of Jane's house. There the women opened a linen cloth, ominously pinned shut, which revealed 'the marks or sign of the birth of a child' and the bloody stains made by 'a lying-in woman'. Eventually, Jane admitted that she had been delivered of a dead baby and told them where to find it.

What can we really know of the subjectivities of those involved? Williams entered the historical record solely due to this episode: she is refracted through the traces of these events in the legal record. The transcript of her examination is merely a few lines long. It says literally nothing about her subjective experience of pregnancy, childbirth, the dead baby or what she did with its body. When we read Jane's examination and her neighbours' depositions, we nonetheless imagine what they must have felt and thought. We construct from these fragments a story by filling rather a lot of gaps (or filling gaps with rather a lot). Our assumptions about the thoughts and feelings of women accused of infanticide are not spun from thin air, of course, but arise from our engagement with evidence and other stories we have read or heard. Yet the perspective from which we approach such evidence perhaps privileges the telling of one type of story over other ways of understanding it historically (see also discussion in Chap. 4).

An unintended consequence of modern scholars' empathy for infanticidal mothers and condemnation of the Concealment Act has been to sensationalise the topic. Illegitimate pregnancy is frequently depicted as a circumstance in which a girl stood to lose everything: her livelihood, her home, her reputation, her friends, her future. Infanticide was an 'inevitable' response to the 'intolerable' shame or 'practical impossibility' of rearing a bastard. ${ }^{6}$ Suspected women are assumed by most historians to have been guilty. Certainly, some women confessed that they had acted 'in hope to keep it private and herself from further shame, and to keep the grief and shame of it from her friends'. ${ }^{7}$ Yet a simultaneous assumption of both guilt and blamelessness hinders our understanding of meaning for 
contemporaries. For early modern people were aware that infanticide did not inevitably or usually follow an illegitimate pregnancy.

First, bastardy was commonplace and infanticide was not. By the early seventeenth century, long-term demographic growth had resulted in 'a brutal deterioration' in opportunities to marry and form households. ${ }^{8}$ Bridal pregnancy remained high-some 25 per cent of married couples' first-born children were conceived before marriage-and bastardy rates increased. Of every hundred live births, between two and five were illegitimate, though precise figures varied over time, region, even parish to parish. In Wales and in western and northern England, the illegitimacy rate could be twice that of the east and south. ${ }^{9}$ But there was unlikely to be a single parish anywhere in which inhabitants did not know someone who had given birth to, fathered, or was a bastard.

Second, and conversely, most people never knew an infanticide in their own parish in their lifetime. Richard Gough, for instance, identified 16 bastards (and suspected at least four more) among the inhabitants of his Shropshire parish at the turn of the eighteenth century, but he recalled no suspected infanticide. ${ }^{10}$ In 1763, Great Sessions judges noted that Margaret Evans' trial for concealment was the first in Caernarvonshire 'within the memory of the eldest person'; ${ }^{11}$ the last case 34 years before had not reached trial after the Grand Jury threw out the indictment. ${ }^{12}$ Seventeenth- and eighteenth-century Welsh counties saw on average one prosecution every four to seven years, which constituted less than 2 per cent of felonies. ${ }^{13}$ In the counties of north-western and north-eastern England, there was rarely more than one prosecution every two to four years. Even in the south-east, there might be less than one annually; in densely populated Essex, 86 per cent of parishes saw no-one prosecuted for infanticide ever. ${ }^{14}$ In London, where all crimes were more numerous, the Old Bailey Sessions Papers reported an average of two cases annually between 1674 and 1750, amounting to 0.7 per cent of homicides and felonious property crimes combined. ${ }^{15}$ In short, most individuals did not know personally a single person tried for newborn child murder.

Third, unexplained deaths of newborns were not necessarily suspicious, even when mothers were unmarried, given infant mortality rates. Of every hundred babies born alive in the seventeenth century, two died within a day, four in the first week and up to ten within a month. In London's poorest areas, infant mortality was around 30 per cent. ${ }^{16}$ London's General Bill of Mortality for 1702 listed only ten murders of victims of all ages, 
but 513 infants stillborn and a further 90 who perished by unintentional overlaying by parents or nurses. ${ }^{17}$ Weekly Bills of Mortality present a similar picture: for example, in one week in April 1715, nine infants were stillborn and one was overlain; in January 1720, 12 were stillborn and two overlain. $^{18}$

Elizabeth Cellier's proposal for a foundling hospital and midwives' corporation in 1687 estimated that during the preceding two decades more than 13,000 babies had been stillborn and a further 5000 had died before baptism - these included children born outside marriage, but were distinguished from those 'willfully murdered by their wicked and cruel mothers, for want of fit ways to conceal their shame, and provide for their children'. ${ }^{19}$ Even when unmarried women were suspected, coroners' inquests did not always conclude that a crime had been committed. ${ }^{20}$

High infant mortality rates did not, however, result in dead babies being objects of emotional indifference. ${ }^{21}$ Early modern people expressed genuine concerns about the spiritual well-being of such infants. Thus, after Ann ferch John had confessed and her baby's body viewed, two other women washed the child, put it in a linen cloth, and carried it to the churchyard, where it was 'buried by one Richard Mathew, the clerk of the parish $[\ldots]$ without a minister' ${ }^{22}$ The notion that chrisom children (who died before baptism) did not enter heaven could make newborn child murder seem especially heartless, as could contemporary medical theories that newborn bodies were incredibly sensitive to pain and should be handled gently. ${ }^{23}$

Some historians have spoken of an early modern 'infanticide wave', or 'infanticide craze', which made newborn child murder prosecuted under the Concealment Act 'one of the distinctive offences' of the period (see also Chap. 4). ${ }^{24}$ Yet in the context of bastardy, infant mortality and other prosecutions for homicide and felonious crime, infanticide or concealment of infant death was absolutely and relatively rare. Neonaticide was clearly not a default path for unmarried pregnant women, even when marriage to the child's father was impossible. Of course, individuals' lack of direct experience of infanticide does not itself mean that it was not a prevalent social issue. Yet I shall argue below that responses to the realities of infanticide do not suggest that people were gripped by a widespread moral panic, despite the concerns of some Members of Parliament in 1624.

The narrative of progress that informs much infanticide historiography has also had implications for the way scholars have imagined the emotions 
of those touched by child-killing. While some continuities and 'remarkable parallels' with the seventeenth century have been noted, similarities tend largely to be identified from the mid-eighteenth century onward. In particular, a high acquittal rate has been attributed to the development of modern sensibilities: new attitudes of pity and compassion towards accused women; reappraisals of medical evidence, and the tightening up of rules of evidence in the courtroom. In this account of change, eighteenthcentury juries' new-found understanding that defendants 'deserved more sympathy than censure' made them less willing to convict. In contrast, it is assumed that seventeenth-century ' $[\mathrm{s}$ ] ociety ... assumed that all unmarried pregnant women were lewd and sinful and thus inclined to indulge in the barbaric and unnatural act of baby-slaying', and 'both prosecution and conviction rates were high' as the 1624 statute was 'effective[ly] implement[ed]'. ${ }^{25}$ From such a perspective, the Concealment Act and those who implemented it in the seventeenth century seem draconian, ruthless and cruel. ${ }^{26}$ Scholars typically characterise those involved in prosecutions in restricted, dichotomous terms. The editors of a Special Issue dedicated to the history of British infanticide presented only two options: 'Was infanticide [either] regarded with fear and loathing, as we might expect, or was ... [it] accepted as a form of extreme population control?'27 But people's emotional responses to newborn child murder and the concealment of bastard deaths cannot be reduced simply to utter abhorrence or complete acceptance or indifference.

Conceiving attitudes to newborn child murder and its prosecution in terms of a 'harsh' seventeenth and 'lenient' eighteenth century distorts our understanding of the past. Not only, as Mark Jackson observed, were attitudes to women accused of newborn child murder at the end of the eighteenth century 'more heterogeneous, and often more hostile' than the 'humanitarian' narrative of change allows, ${ }^{28}$ but we must also reconsider our view of the seventeenth century. The notions that unmarried women concealed their pregnancies due to their modesty and virtue rather than an unnatural cruelty, and that they deserved pity rather than condemnation were not new in 1750 nor even in 1700. These ideas coexisted during the entire period in which the Concealment Act was on the statute books. That is not to say that nothing changed between 1624 and 1803 but rather to suggest that the dichotomous, teleological view of both the infanticidal mother and attitudes to child-killing will not suffice. 


\section{Condemnation And Compassion}

If the killing of innocent babes was genuinely shocking and was associated with unmarried women who concealed pregnancies, we might expect to find it a common topic of discourses that railed against sin and crime. Certainly, preachers such as William Gouge denounced neonaticidal mothers of bastards as 'lewd and unnatural', while the authors of legal tracts identified such women as 'harlots' and 'lewd whores'. ${ }^{29}$ Popular genres of cheap print fleshed out the infanticidal mother's story under sensationalist titles, following the route from routine sinfulness to the murder of an innocent babe, to the providential discovery of the crime, and thence to trial and punishment. Thus, a ballad No Natural Mother but a Monster (1634) charted a young woman's journey from disobedience, 'unbridled will' and 'wild' behaviour, via fornication to hidden pregnancy, secret birth, and strangling her 'poor harmless infant quite against nature's law', to discovery and execution. The ballad ends with her lamenting her 'barbarous wickedness that foully did transgress thus against nature' as she waited, penitently, for death. 'Let not', she exhorted listeners, 'the fear of shame so prevail ... as to win you the name of cruel mother', who is 'more cruel' than 'savage creatures' such as snakes and tigers. ${ }^{30}$

The 1624 legislation did not create such rhetoric but was informed by it. Anthony Munday similarly described in 1580 a maidservant who 'had abused her body with unchaste living, and being delivered of a sweet and tender infant, calling all motherly and natural affection from her; buried the same alive'. ${ }^{31}$ One of the two murders tried at the Old Bailey in July 1614, which were the subject of a pamphlet Deeds against Nature and Monsters by Kinde, was that by 'a lascivious young damsel', who, so 'that the world might not see the seed of her own shame', took 'the poor tender babe as it were new dropped from [her] womb, and not like a mother, but a monster threw it down into a loathsome privy house, therein to give it an undecent grave'. ${ }^{32}$ Such condemnations and the 1624 Act itself have led some scholars to remark that the early modern 'popular press show[ed] an almost obsessive concern with female violence', and that 'unmarried mothers [were] considered the most prolific killers and certainly the most vilified'. ${ }^{33}$

However, neither popular crime literature nor its terminology was especially associated with women prosecuted for concealment or neonaticide. Indeed, the first murder discussed in Deeds against Nature was that of a man who strangled his wife 'to hide his shame and lust'. He too was 
'a Monster by kind and the doer of a deed against nature'. ${ }^{34}$ Of numerous crime pamphlets written by prison chaplain, Henry Goodcole, only one concerned women who murdered their own offspring. In Natures Cruel Step-Dames: or, Matchless Monsters of the Female Sex, Goodcole was primarily interested in Elizabeth Barnes, a widow who slit her eight-yearold daughter's throat while she was sleeping, having taken the child deep into the woods for a picnic (apple pie, herring pie, raisins, and other fruits, the same delicious 'baits, used by loving parents to quiet and still their children in their unquietness'). Goodcole discussed Barnes' behaviour and its meaning over 16 pages. Anne Willis, who had thrown her newborn bastard into the privy, he dealt with in a single page. ${ }^{35}$

Unlike other relatively rare violent offences associated with women, such as petty treason and witchcraft, neonaticide was not a prevalent theme in street literature. The explanation is not, as some have suggested, that a high incidence of newborn child murder rendered it too 'mundane' and typical to excite a public used to reading about more sensational killings. ${ }^{36}$ For, as we have seen, neonaticide was neither mundane nor typical. Concealment of pregnancy and the deaths of illegitimate newborns were not well suited to the crime narrative genre for other reasons. Notwithstanding the portrayal of infanticidal mothers as lewd, sinful creatures, such women were also culturally the objects of some sympathy.

The most obvious reason for this is ambivalence towards the Concealment Act itself. As I have shown elsewhere, contemporaries distinguished between cases based on positive evidence of murder that met standards of proof in regular homicide law, and those which rested solely upon concealment of death. The Act thus had a low conviction rate and convicted women were far more likely to be reprieved and pardoned than they were for any other category of homicide. Crucially, this was not an eighteenth-century development, but began in the 1620 s almost as soon as the statute came into force ${ }^{37}$ After the Old Bailey trial jury found Elizabeth Draper guilty in 1626, for example, efforts to secure her pardon included the coroner, the midwife, the surgeon and the jury foreman all certifying that the coroner's jury 'would not find her guilty at all' despite pressure from the coroner, because 'the evidence touch[ed] merely the concealment of the statute', and 'the midwife swore the child was born dead and the surgeon could not find any wound or bruise'. ${ }^{38}$ In other words, without positive evidence that the infant had been murdered, the jury were reluctant to find Draper guilty even though technically the evidence for concealing the death met the criteria for conviction. 
Reprieves and pardons were frequently based on same pretext: when evidence pertained to concealment alone and 'not actual nor malicious killings' ${ }^{39}$ Many such pardons were, significantly, free pardons, not conditional upon transportation or other mitigated punishment. It was as a development of these practical rejections of the strict terms of the Concealment Act from the 1620s onwards that the 'linen defence' emerged, whereby preparations for the infant's arrival such as the provision of clothes and linens became accepted as one of the 'divers circumstances' that 'made it probable that the child was stillborn' and which very often resulted in acquittal regardless of concealment. ${ }^{40}$

Sympathy for unmarried women prosecuted for neonaticide was connected also to their entire predicament. The conventional script which provokes empathy of modern scholars had a similar effect on many contemporaries. The Old Bailey Proceedings described Joan Blackwell as 'an object of Compassion to most People present' at her 1679 trial. The 'poor young Wench', who had been 'betrayed ... by a promise of marriage', was thrown out and physically forced into another parish by her landlady while she was actually in labour: 'this poor Creature' gave birth 'in this sad condition in the street, and without any help'. Watchmen found her thus, 'lying as one half dead', and a midwife called to the scene found the child dead but not separated from Joan's body. Joan herself did not claim stillbirth—she said she had heard the baby cry—but insisted she had not killed it. Both the Proceedings and the Ordinary's Account, in which readers learned of her reprieve, suggested that 'the poor creature ... was convicted only upon the severity of the Statute'. ${ }^{41}$ Pity was directed towards women presumed to have killed their babies, not just those whose guilt was doubtful. A trial pamphlet author in 1664 described Mary Smith, who had decapitated her newborn baby, thrown its body out of a ship's porthole and hidden its head in the hold, as a 'bloody mother' yet also lamented that 'never came a more penitent soul within the walls of Newgate, than this poor creature'. ${ }^{42} \mathrm{Mr}$ Bay, a parish officer, used the same phrase when he testified against Mary Shrewsbury in 1737, even though by then he was aware that she had hacked at her newborn infant's throat so violently that its head was almost severed from the body and had afterwards sewn its corpse into a cloth. Called to her house after she had confessed, Bay had found 'the poor creature ... sitting upright in her bed, with a book in her hand, and the tears ran plentifully down her face'. ${ }^{43}$ In the early modern period, the term 'poor creature' was an accepted expression denoting compassion and commiseration. 
Blackwell, Smith, and Shrewsbury's stories indicate another reason for people's ambivalence towards neonaticides: the part played by men who had impregnated them. All three claimed to have been 'betrayed' by men who had promised them marriage but had 'deluded', 'seduced and debauched', and abandoned them instead. ${ }^{44}$ Men's responsibility for the plight of women who concealed pregnancies, births and deaths of bastards problematised the attribution of sole culpability to such women. ${ }^{45}$ The terms of the 1624 Act and the nature of secret birth meant that few fathers of victims were prosecuted either as accessories to concealment or as principals for murder. ${ }^{46}$ When they were, they were seldom convicted. Yet acquittals did not automatically connote innocence for contemporaries. At Taunton, in April 1720, for example, newspapers commented on a man who had been acquitted as an accessory to the murder of the bastard child he begot on his maidservant, which child he delivered. His servant was convicted under the Concealment Act (though reprieved). The newspaper declared that acquittal reflected not his innocence but 'the evidence not being sufficient against him' to convict, 'notwithstanding which, it is violently suspected he has been guilty of several of the like Facts' ${ }^{47}$

Thomas Brewer's pamphlet, The Bloudy Mother, dramatised men's duplicity even while condemning Jane Hattersley as a 'most graceless, audacious and impudent beast (too bad to bear the good name of woman)'. Hattersley's lengthy affair with her 'rank and corrupted' master, Adam Adamson, produced several illegitimate pregnancies, which she concealed 'with loose lacing, tucking and other odd tricks'. She murdered the infants; Adamson 'secretly buried [them] in a grave of his own making'. After the murders were exposed, Adamson 'did very cunningly and as closely work on her simplicity' to save his own neck. Adamson persuaded Hattersley to confess that she was solely responsible, telling her that her feigned honesty and penitence would so impress judge and jury that they would almost certainly acquit her, but that if she were convicted, Adamson would easily secure her the King's pardon. Hattersley was thus convicted alone. Even 'in the last minute of her breath', Hattersley did not denounce Adamson, because he had convinced her that changing her story 'should frustrate her pardon'. In 'that fear, and hope of life', with the rope around her neck, 'she gave the hangman six pence to cut her down quickly' so she might only be 'half dead' when 'the pardon would come, and save her in that heavy gasping: but her belief was vain, and her vain hopes were deceived, for as she deserved she there died'. So it was that even a vile, murderous creature was transformed by Brewer into an 
object of pity as she waited in vain to be saved by the treacherous man whom she loved. But Brewer's tale did not end there. Adamson got his comeuppance, suffering providentially from a horrid affliction in which worms and lice devoured him alive from the inside out. He died, stinking of carrion, within six months. The message was clear: Adamson came to the end he deserved, just as Hattersley had. ${ }^{48}$

\section{Discovery AND Dismay}

Attitudes to neonaticide were informed also by sentiments towards infant victims. Early modern people were used to death, especially deaths of small children, and to the sight of bodies which were prepared for internment at home. However, these routine encounters did not inure them to the discovery of concealed infant death-not only because of the potential sight and smell of crushed, slashed, or rotting corpses but also because of the importance placed on both the preparation of bodies for burial and the location of graves. ${ }^{49}$ Unexpectedly finding a newly deceased baby was itself disturbing. When Margery Jenkyn 'out of compassion' attended to a sick neighbour who lived alone in a 'little hovel', she 'put her hands under the [bed]clothes to know if she lay warm and looking into the bed', she saw 'a dead child which did so startle her that she cried out'. An eleven-yearold girl who was present said that Margery had 'beat her breast' as well as crying out when she saw the dead child. ${ }^{50}$

Elsewhere, maidservant Jane Lloyd 'came running downstairs in great terror and fear clapping her hands together saying "Oh Aunt! Aunt! ... yonder woman's child is dead!"'. ${ }^{11}$ Such a shock was exacerbated by one's unpreparedness to find a child there at all, perhaps, but some circumstances made discovery particularly dreadful. Two women and some children, spying Gwen Griffith oddly scraping and treading down the earth on a mountainside, 'digged up that place with a piece of stick' and 'found a little blood with a leg and a foot of a dead child'. This so 'frightened' them, that 'they threw down the earth again and got two stones and laid [them] on it for fear of any dogs or other things to dig it up'. They then 'went their ways and told everybody' that they had found a dead child. ${ }^{52}$

The jolt of discovery was felt even when people knew what they were looking for. The women who found Jane Williams's baby's corpse precisely where she directed them were 'so terrified and surprised' that they 'did not touch the child at that time' and left it where it was. ${ }^{53}$ The 'surprise' was that of the early modern sense of being emotionally overcome. 
Others took up infant corpses immediately they discovered them: Mary Walter, seeing a little dog biting and fondling 'some prey', upon closer inspection discovered a dead child whose leg had been devoured by the dog and was so mutilated that it was impossible to determine the baby's sex. She took the child straight to the nearest house, 'called for the family to see it and asked the meaning of it', after which they returned the corpse to the place she had found it and sent for the magistrate and constable. ${ }^{54}$

While people were willing to extend the benefit of doubt to suspects whose babies exhibited no signs of violence having been inflicted, they were affected by apparent evidence to the contrary. In 1670, every one of the female witnesses described minutely the condition of a dead baby discovered within a few hours of its birth: 'the child's mouth [was] open and some part of its tongue out of its mouth', with 'some three stripes or strikes on its throat being also blackish, the like sign she had never seen on any child' before. The discoloration-the baby was 'black and blue', 'blackish about the throat and brownish also'-distinguished this death from a natural one, for the 'child was warm', which suggested these marks were impressed upon it while it was still alive, with 'its mouth open' as if it were gasping for air or reaching for the breast. ${ }^{55}$ In 1673, Thomas Davies discovered a newborn's corpse in a flax loft, which 'had been there so long till it stunk'. He brought another manservant to look upon it, who asked him what they should do, to which Thomas replied, 'We will not discover [tell] anyone [f]or the curse of anybody shall not fall upon us'. Yet when a few days later he saw the girl suspected to be its mother 'merry and laughing', he told her: 'You need not be so merry for I have seen the dead child', to which 'she did not answer anything'. ${ }^{56}$ People could have strong reactions to the corpses of newborns. But those responses, even when they led to prosecution, are not best understood simply as part of 'a shaming process intended to discipline the sexually illicit woman and expose her $\sin { }^{57}$

\section{Suspects' Subjectivities}

Analyses of infanticide tend to situate the women concerned in a fixed and limited emotional landscape: as desperate victims of a patriarchal society in which the shame of bearing an illegitimate child compelled them to become, as Lawrence Stone put it, 'the deliberate butcher of her own bowels'. ${ }^{58}$ Sometimes they are presented as protofeminists. Marilyn Francus imagined only two subject positions: they were either 'submissive' women 
who internalised the dominant gender ideology and killed their newborns to sustain their place within it, or 'rebellious' non-maternal ones who violently dispatched their infants as a rejection of gender norms. ${ }^{59}$ Either way, suspected women seem to be purposeful, goal-oriented agents (and guilty of the offence). Yet as Laura Gowing argued, neither concealment of pregnancy nor child-killing were necessarily calculated or even fully conscious acts. ${ }^{60}$ In 1713, for instance, Mary Ellis, who gave birth on a mountainside on the way to her mother's house, described being 'in such agony and in a sound [faint] at her delivery, she did not know well whether the child was dead or alive'. After 'she had come to herself', she continued on, but realising that the child was dead, she being 'light headed or insensible' due to 'the great agony which she had at her delivery [..., ] having found a little river she laid it there, she knowing not what she did'. ${ }^{61}$

Much work on early modern child-killing seems to belie 'the deep, complex and varied individual emotional experiences' of suspected women and girls, just as it has tended to flatten or polarise the responses of their contemporaries. ${ }^{62}$ Scholars often posit a 'single, isolated subjecthood' or singular 'subject position' for suspects, the sort of 'self' that oral historians have long rejected. ${ }^{63}$ I suggest that we seek in these sources not 'the real historical subject', but rather be sensitive to the multiple subject positions that could be assumed by one individual. ${ }^{64}$

For example, in witness testimony and her own examination in 1716, one may perceive at least three subjectivities of Gwen Foulk. The first is communicated by a neighbour, Dorothy Williams, who deposed that she encountered Gwen 'uneasy and groaning' a few yards from a stile on a common footpath leading to the highway and asked what ailed her. Gwen replied that 'she had a gnawing about the stomach and heart' and, then lay down unable to go further, asking Dorothy to fetch her sister, who lived across the field. The sister being absent, Dorothy returned with Elizabeth Salesbury to find Gwen 'crawling upon her knees and face in an uneasy posture upon the grass'. Elizabeth gave Gwen ginger to bite (a remedy for stomach ailments). But when Gwen handed it back, the women saw that her hand and the grass beneath her were bloody. Suspecting her condition, they urged her to accompany them 'to some house and offer[ed] their assistance to support her (because she complained she was not able to stand)'. Gwen 'obstinately refuse[d]'. They departed but, lingering down the road, observed Gwen 'throw something from her' and leave. Returning 'to see what was left there', they 'found a child (as they took it) covered with the attendants of nature lying in the ditch'. In these 
depositions, Gwen is presented from Dorothy's perspective as an obstinate denier of pregnancy and a concealer of childbirth and we may imagine how desperate she might have felt in such a predicament. Here, the 'typical' infanticidal mother of the historiography may be seen. The account given by Mary Jones, Gwen's mistress, was somewhat different. Arriving home that evening, she found Gwen sitting alone in the dark next to the fire. Gwen spoke in such 'a feeble distressed voice' that Mary did not at first recognise her. Being asked what was wrong, Gwen 'answered nothing but cried'. Dorothy later acquainted Mary with 'the whole history' and showed her the bloody field and dead child. When Mary asked Gwen why she had left the child there, Gwen claimed simply that she had not known what it was. This Gwen is abject, isolated, distressed.

A third subject position emerges in Gwen's own examination: now we see a feisty, intelligent girl who is able to deflect the accusations against her: she was 'unprovided with clothes and other necessaries' for the baby because 'it was but lately that she suspected herself to be with child'; she would not have concealed her condition from Dorothy 'but that the manservant was present $[\ldots]$ and Elizabeth Salusbury was a person whom her master and mistress had no good opinion of'; if Dorothy had been alone, she would have told her. She 'positively denie[d] the child to have had any life in him',

and as circumstances to clear her from having hatched any ill designs, she says none of the family was at home, [so] that the mansion house or outhouses and other fields or by places might have sheltered her better than a common public field that had so many footpaths in it and surrounded by several highways especially in that part of it which was directly on the path near the style and highway, and that she first complained of ailings to [...] Dorothy before she was asked any questions and laid herself down in her presence which she would not have done had she designed to conceal her condition. ${ }^{65}$

What are the implications of discerning Gwen's multiple selves? We must acknowledge that these are not coherent narratives from which we can reconstruct fixed, authentic subjectivities. These sources suggest something of subjectivity in very particular contexts. Of these three 'Gwens', only one is conveyed through words allegedly spoken by her, and those words were, of course, actually those of a clerk who was not required to produce a verbatim transcript but to record only as much as was legally 
relevant. ${ }^{66}$ However, the subjectivity we meet in Dorothy and Mary's accounts is no more or less 'authentic' if we reject a notion of the 'self' as a pre-existing entity to be uncovered by brilliant analysis (historical or otherwise). Gwen's experience of giving birth in the field was affected by Dorothy, the manservant, and Elizabeth's presence there; if they had been absent, her experience would have been different. Thus, the 'self' we may discern in these sources was coproduced in the moment where the parties met with all the contextual weight that implies. ${ }^{67}$

Nor can we position Dorothy and Mary as, respectively, simply condemnatory and sympathetic. Dorothy, for all her interfering, testified that 'she thought that [the child] had not been alive, for it was so very little and unlike children of full age'. Mary, for all her concern, came straight from the field where she viewed the infant's body to the house into Gwen's bed-chamber and confronted her, asking 'what frolics she played in their absence that evening'; yet she too swore she believed the child had been stillborn 'for it had not the full share of flesh as such [newborns] used to have but seemed wasted'. How people feel, what they think, how they are affected, may change from moment to moment, and we are fortunate to have sources that allow us to discern how complicated child death was for early modern people, as it is for us.

\section{Conclusion}

Let us end where we began, with Jane Williams in 1734. Here, too, we can perhaps see that a mere fragment might provide us with some sense of emotion that does not rely on our discovering a conscious, fixed subject. Alternative subject positions might be simultaneously occupied. Jane's conviction rested primarily on 'observed marks of violence' on the baby's throat and neck, 'the skin being chaffed off as it had been with a hand in two several places'. Any violence Jane inflicted, however, sits in tension with one way of understanding how she dealt with its body, which speaks not just of the extraordinary but also the everyday, not only of violence but also possibly of nurturing, not just of death but also, in a way, of life. Jane laid her dead baby 'under a stone under the hen's nest in a [passageway] in her dwelling house'. ${ }^{8}$ We cannot know whether this was a temporary hiding place or a permanent grave, whether Jane had spent several days determining the best place to bury the infant, or whether she laid it there in a moment of panic. After all, in February, when the hens were not laying, it might seem an attractive location unlikely to be disturbed. Yet 
whether it was a pragmatic, calculated, panicky or unthinking act, placing the body there in that specific spot may nonetheless have some emotional meaning.

As Jane went back and forth each day, she would pass her baby, perhaps many times. Her baby was not left to the cold under a rock on an isolated hillside or thrown in a dung-hill to be unearthed by dogs or swine. Rather she placed it carefully under a different stone, which was under a nest, which was under an egg, which was under a hen. This baby, whom Jane had secretly carried in her womb, but whose birth, whose death, she had not acknowledged to a soul, was now perpetually like an egg, kept safe and warm by a surrogate mother, and when an egg was taken from the nest, very possibly collected by Jane herself, the hen would lay another egg, and then another, and so on and on. Thus, in a way, it was as if the baby had never been and never would be born, but would always be in a state of becoming. Conscious, unconscious or semi-conscious, coldly calculated or barely recognised? We cannot know. Jane herself might not have been able to tell us. These subject positions are partial, fragmented, and cannot be pinned down. But given that we are talking about speech recorded in legal contexts, in response to very specific questions, about events that took place three hundred or so years ago, then that is surely enough of a gain.

\section{Notes}

1. Research for and writing of this chapter was made possible by a Leverhulme Trust Major Research Fellowship.

2. An Act to Prevent the Destroying and Murdering of Bastard Children, 21 James I, c. 27 (1624).

3. Similar legislation was passed in the Holy Roman Empire (1532) and was reinforced in individual territories by numerous statutes in the following two centuries, and in France (1556), Scotland (1690) and Ireland (1707). See also Chap. 4.

4. National Library of Wales [hereafter NLW], Great Sessions of Wales: Gaol Files [hereafter GS] 4/178/2/22 (1734).

5. For example, Peter Charles Hoffer and N.E.H. Hull, Murdering Mothers: Infanticide in England and New England, 1558-1803 (New York: New York University Press, 1981); Mark Jackson, New-Born Child Murder: Women, Illegitimacy and the Courts in Eighteenth-Century England (Manchester: Manchester University Press, 1996); Laura Gowing, 'Secret Births and Infanticide in Seventeenth-Century England', Past \& Present 156 (1997), 87-115; Garthine Walker, 'Just Stories: Telling Tales of Infant 
Death in Early Modern England', in Culture and Change: Attending to Early Modern Women, ed. Margaret Mikesell and Adele Seeff (Newark and London: University of Delaware Press and Associated University Presses, 2003), 98-115.

6. Marilyn Francus, Monstrous Motherhood: Eighteenth-Century Culture and the Ideology of Domesticity (Baltimore: Johns Hopkins University Press, 2012), 21; Randall Martin, 'English Child-Murder News and the Culture of Equity', in Masculinities, Childhood, Violence: Attending to Early Modern Women - and Men, ed. Amy E. Leonard and Karen L. Nelson (Newark: University of Delaware Press, 2011), 272; Susan Dwyer Amussen, An Ordered Society: Gender and Class in Early Modern England (New York: Basil Blackwell, 1988), 132.

7. Examination of Mary Gash, Southampton, 1649: The Book of Examinations and Depositions before the Mayor and Justices of Southampton, 1648-1663, ed. Sheila D. Thompson (Southampton: Southampton Record Society, 1994), 37: 27-9.

8. Keith Wrightson, Earthly Necessities: Economic Lives in Early Modern Britain (New Haven: Yale University Press, 2000), 223.

9. Peter Laslett, 'Introduction', in Bastardy and its Comparative History: Studies in the History of Illegitimacy and Marital Nonconformism in Britain, France, Germany, Sweden, North America, Jamaica, and Japan, ed. Peter Laslett, Karla Oosterveen and Richard Smith (London: Edward Arnold, 1980), 1-65; Keith Wrightson, 'The Nadir of English Illegitimacy in the Seventeenth Century', in Bastardy and its Comparative History, ed. Laslett, Oosterveen and Smith, 176-91; Richard Adair, Courtship, Illegitimacy, and Marriage in Early Modern England (Manchester: Manchester University Press, 1996), 25-7, 63, Table 2.8.

10. Richard Gough, The Antiquities and Memoirs of the Parish of Myddle (Shrewsbury: Adnit and Naughton, 1875), 39, 45-6, 57, 72-3, 90, 110, $130,132-3,142,146,148,152,161$; one older boy was murdered by a male relative, 72 .

11. The National Archives [hereafter TNA], Secretaries of State: State Papers: Entry Books, SP 44/87, f.180, Earl of Halifax to Lord Mansfield, 13 April 1763; Daines Barrington and James Hayes to Lord Halifax, 7 April 1763. GS 4/274/2/23, indictment of Margaret Evans (Caernarfonshire, 1762).

12. GS $4 / 272 / 1$, indictment of Ellin Morris (Caernarfonshire, 1745).

13. Sharon Howard, Law and Disorder in Early Modern Wales: Crime and Authority in the Denbighshire Courts, c. 1660-1730, Chapter 3; figures from 1730 calculated from NLW, Crime and Punishment Database, https://www.llgc.org.uk/sesiwn_fawr/index_s.htm, accessed 24 August 2015 . 
14. Gowing, 'Secret Births', 89; Garthine Walker, Crime, Gender and Social Order in Early Modern England (Cambridge: Cambridge University Press, 2003), 150; J.R. Dickinson and J.A. Sharpe, 'Infanticide in Early Modern England: The Court of Great Sessions at Chester, 1650-1800', in Infanticide: Historical Perspectives on Child Murder and Concealment, 1550-2000, ed. Mark Jackson (Aldershot: Ashgate, 2002), 38; J.A. Sharpe, Crime in Seventeenth-Century England: A County Study (Cambridge: Cambridge University Press, 1983), 135; Keith Wrightson, 'Infanticide in Earlier Seventeenth-Century England', Local Population Studies 15 (1975), 11-12, 14, 18-19.

15. Figures calculated from Old Bailey Proceedings Online (www.oldbaileyonline.org, version 7.2), accessed 24 August 2015.

16. Richard Smith and Jim Oeppen, 'Place and Status as Determinants of Infant Mortality in England, c.1550-1837', in Infant Mortality: A Continuing Social Problem, ed. Eilidh Garrett et al. (Aldershot: Ashgate, 2006), 53-78; Jeremy Boulton, Neighbourhood and Society: A London Suburb in the Seventeenth Century (Cambridge: Cambridge University Press, 1987), 125; R.S. Schofield and E.A. Wrigley, The Population History of England, 1541-1871 (Cambridge: Cambridge University Press, 1981), 249; Ralph Houlbrouke, Death, Religion and the Family in England, 1480-1750 (Oxford: Oxford University Press, 1998), 7-9.

17. Flying Post or the Post Master, 24-26 December 1702.

18. Weekly Journal with Fresh Advices Foreign and Domestick, 30 April 1715; Weekly Journal or British Gazetteer, 9 January 1720.

19. Elizabeth Cellier, 'A Scheme for the Foundation of a Royal Hospital ... 1687', in The Harleian Miscellany, ed. Thomas Park (London: White and Co, 1809), 4: 142-7.

20. Walker, Crime, Gender and Social Order, 149-50.

21. Few historians now agree with the model of the non-affective preindustrial family argued for in, among others, Lawrence Stone, The Family, Sex and Marriage in England, 1500-1800 (London: Weidenfeld and Nicolson, 1977).

22. GS 4/153/2/14 examinations re. Ann ferch John (Montgomeryshire, 1648).

23. Will Coster, 'Tokens of Innocence: Infant Baptism, Death and Burial in Early Modern England', in The Place of the Dead: Death and Remembrance in Late Medieval and Early Modern Europe, ed. Bruce Gordon and Peter Marshall (Cambridge: Cambridge University Press, 2000), 287-89; Walker, 'Just Stories'; Hannah Newton, The Sick Child in Early Modern England, 1580-1720 (Oxford: Oxford University Press, 2012), 40.

24. For 'infanticide craze', see Dickinson and Sharpe, 'Infanticide in Early Modern England', 36; Susan C. Staub, Nature's Cruel Stepdames: 
Murderous Women in the Street Literature of Seventeenth-Century England (Pittsburgh: Duquesne University Press, 2005). For 'infanticide wave', see Sharpe, Crime in Early Modern England, 87-8, 158.

25. Mary Clayton, 'Changes in Old Bailey Trials for the Murder of Newborn Babies, 1674-1803', Continuity \& Change 24, no. 2 (2009), 337-59, at 340; Jackson, 'Trial of Harriet Vooght', 3, 6, 11; Jackson, New-Born Child Murder, 110-32; Dana Y. Rabin, Identity, Crime, and Legal Responsibility in Eighteenth-Century England (Basingstoke: Palgrave Macmillan, 2004), 95.

26. For example, Francus, Monstrous Motherhood, 99; Josephine McDonagh, 'Infanticide and the Boundaries of Culture from Hume to Arnold', in Inventing Maternity: Politics, Science, and Literature, 1650-1865, ed. Susan C. Greenfield (Lexington: University Press of Kentucky, 1999), 217; Frank McLynn, Crime and Punishment in Eighteenth-Century England (London and New York: Routledge, 1989), 110-15.

27. Anne-Marie Kilday and Katherine Watson, 'Infanticide, Religion and Community in the British Isles, 1720-1920: Introduction', Family \& Community History 11, no. 2 (2008), 85.

28. Jackson, New-born Child Murder, 128.

29. William Gouge, Of Domesticall Duties (London: John Haviland ..., 1622), 507; Zachary Babington, Advice to Grand Jurors in Cases of Blood (London: John Amery, 1677), 174.

30. Edward Parker, No Natural Mother, but a Monster ... (London: F. Coules, 1634).

31. Anthony Munday, View of Sundry Examples, Reporting Many Straunge Murthers (London: [J. Charlewood] for William Wright ..., 1580), sigs. C2r-C2v. See also T[homas] J[ohnson], A World of Wonders ... (London: [printed ...] for William Barley ..., 1595), sig. F2r.

32. Deeds against Nature, and Monsters by Kinde Tryed at the Gaole Deliverie of Newgate ... (London: printed [by G. Eld] for Edward Wright, 1614), sigs. A3v, A4r.

33. Staub, Nature's Cruel Stepdames, 7; Vanessa McMahon, Murder in Shakespeare's England (London: Hambledon and London, 2004), 126 [covers period to 1730]. Staub cites 25 ballad titles depicting female murderers 1569-1640, but these constituted a fraction of thousands published on other topics: see Angela McShane, 'Ballads and Broadsides from the Beginning to 1600', in The Oxford History of Popular Print Culture, ed. Joad Raymond (Oxford: Oxford University Press, 2011), 339-62.

34. Deeds against Nature, sig. Alr.

35. Natures Cruell Step-Dames: or, Matchlesse Monsters of the Female Sex (London: Francis Coules ..., 1637), 1-17. 
36. Sandra Clark, Women and Crime in the Street Literature of Early Modern England (Basingstoke: Palgrave, 2003), 36; Bernard Capp, 'Popular Literature' in Popular Culture in Seventeenth-Century England, ed. Barry Reay (London: Croom Helm, 1985), 10.

37. Walker, Crime, Gender and Social Order, 148-58.

38. TNA, Secretaries of State: State Papers Domestic, Charles I, SP 16/64, f.125, draft certificate to Philip Earl of Montgomery, 26 May 1626; SP 16/230, f.172 (n.d.). See also TNA, Signet Office and Home Office: Doquet Books and Letters Recommendary, SO 3/8, Pardon to Joan Oliver, April 1624; SO 3/9, Elizabeth Riddington, July 1628; SO 3/9 Ellen Hawarth, August 1628; SP 16/368, Recorder's report re. Joan Ashby, 22 September 1637.

39. TNA, Secretaries of State: State Papers Domestic, Charles II, SP 29/24 f.245, Petition of Alice Raves, Mary Key, Mary Lilly, Mary Kingerby, Mary Jackson, Katherine Huddleston and Mary Setters in the gaols of Warwick, Nottingham, and Lincoln, 31 December 1660.

40. SP 44/28, f.126, warrant to reprieve Judith Ansell, 11 March 1675.

41. OBP [Joan Blackwell] October 1679, t16791015-2; Ordinary's Account OAl6791024.

42. The Last Speech and Confession of Peter Caesar [...] A True Relation Concerning Mary Smith ... (London: Charles Gustavus, 1664), 4.

43. OBP, Mary Shrewsbury, February 1737, tl7370216-21; Ordinary's Account, March 1737, OA17370303.

44. OBP, October 1679, t16791015-2 (Blackwell); Last Speech and Confession ... Mary Smith, 4; Ordinary's Account, March 1737, OA17370303 (Shrewsbury).

45. For the relative criminal culpability for homicide, see Walker, Crime, Gender and Social Order, 113-58.

46. For example, Thomas Oarson (Lincolnshire), SP 16/233, f.140, 1632; Joseph Axly (London/Middlesex), OBP, September 1683, t16830223-9; William Doling (Dorchester), Daily Post, 25 March 1727; George Dewing (Essex), TNA, State Papers Domestic: George II, petition and examinations re. George Dewring, SP 36/6/2, fos.95-102, May 1728.

47. Weekly Journal or Saturday's Post, 20 April 1723.

48. T[homas] B[rewer], The Bloudy Mother, Or the Most Inbumane Murthers ... (London: John Busbie ..., 1610), sigs. B3r, A4r, A4v, B4v, Clr.

49. See Sarah Tarlow, Ritual, Belief and the Dead in Early Modern Britain and Ireland (Cambridge: Cambridge University Press, 2010), 103-55. See also the Scottish example in the Introduction.

50. GS 4/161/4, 75, examinations re. Elizabeth Dafydd Williams (Montgomeryshire, 1681 ).

51. GS 4/26/3/1, examination of Katherine verch Richard (1664). 
52. GS $/ 4 / 33 / 6$, fos.25-27, examinations re. Gwen Griffith (Denbighshire, 1687).

53. GS $4 / 178 / 2 / 23$, examination of Jane Lewis (1734).

54. GS 4/728/1A, examinations re. Maud Thomas (Carmarthenshire, 1696).

55. GS 4/28/2, fos.97-100, depositions re. Dorothy ferch Thomas (Denbighshire, 1670); my emphasis.

56. GS 4/29/2/56-58, examinations re. Gwen Hughes (Denbighshire, $1673)$.

57. Marisha Caswell, 'Mothers, Wives and Killers: Marital Status and Homicide in London, 1674-1790', in Female Transgression in Early Modern Britain: Literary and Historical Explanations, ed. Richard Hillman and Pauline Ruberry-Blanc (Farnham: Ashgate, 2014), 116.

58. Stone, Family, Sex and Marriage, 297.

59. Francus, Monstrous Motherhood, 99-122.

60. Gowing, 'Secret Births'.

61. GS 4/40/8, examination of Mary Ellis (Denbighshire, 1713).

62. Quoting Michael Roper, 'Slipping out of View: Subjectivity and Emotion in Gender History', History Workshop Journal 59 (2005), 59.

63. Celia Lury, Penny Summerfield, and Tess Coslett, 'Introduction', in Feminism and Autobiography: Texts, Theories, Methods, ed. Celia Lury, Penny Summerfield, and Tess Coslett (London: Routledge, 2000), 3-4.

64. See Chap. 12 for a discussion of the role of siblings as multiple selves.

65. GS 4/41/6, depositions re. Gwen Foulk, indictment, coroner's inquest (Denbighshire, 1716); Gwen was acquitted.

66. Walker, 'Just Stories'. Welsh pre-trial testimonies were almost all English translations of words originally uttered in Welsh, the implications of which I shall address elsewhere.

67. The model of the 'self' that I have so far found most helpful is that of Gestalt theory, as it allows for the self to be contingent always on historical, cultural, and personal context. Ansel L. Woldt and Sarah M. Toman, eds, Gestalt Therapy: History, Theory and Practice (London: Sage, 2005).

68. GS 4/178/2/22, 23. 